\title{
Global uptake of carbonyl sulfide (COS) by terrestrial vegetation: Estimates corrected by deposition velocities normalized to the uptake of carbon dioxide $\left(\mathrm{CO}_{2}\right)$
}

\author{
L. Sandoval-Soto ${ }^{1}$, M. Stanimirov ${ }^{2}$, M. von Hobe ${ }^{3}$, V. Schmitt ${ }^{4}$, J. Valdes ${ }^{5}$, A. Wild ${ }^{4}$, and J. Kesselmeier ${ }^{1}$ \\ ${ }^{1}$ Max Planck Institute for Chemistry, Biogeochemistry Dept., Joh.-J.-Becher-Weg 27, 55128 Mainz, Germany \\ ${ }^{2}$ University of Applied Sciences Solothurn, Institute for Automation, 4600 Olten, Switzerland \\ ${ }^{3}$ Research Centre Jülich, Institute of Chemistry and Dynamics of the Geosphere (IGG-I), 52425 Jülich, Germany \\ ${ }^{4}$ Institute for General Botany, University of Mainz, Müllerweg 6, 55128 Mainz, Germany \\ ${ }^{5}$ National University, Atmospheric Chemistry Laboratory, 86-3000, Heredia, Costa Rica
}

Received: 14 January 2005 - Published in Biogeosciences Discussions: 31 January 2005

Revised: 12 May 2005 - Accepted: 29 May 2005 - Published: 15 June 2005

\begin{abstract}
COS uptake by trees, as observed under dark/light changes and under application of the plant hormone abscisic acid, exhibited a strong correlation with the $\mathrm{CO}_{2}$ assimilation rate and the stomatal conductance. As the uptake of COS occurred exclusively through the stomata we compared experimentally derived and re-evaluated deposition velocities $\left(V_{d}\right.$; related to stomatal conductance) for $\mathrm{COS}$ and $\mathrm{CO}_{2}$. We show that $V_{d}$ of COS is generally significantly larger than that of $\mathrm{CO}_{2}$. We therefore introduced this attribute into a new global estimate of COS fluxes into vegetation. The new global estimate of the COS uptake based on available net primary productivity data (NPP) ranges between $0.69-1.40 \mathrm{Tg} \mathrm{a}^{-1}$. However, as a COS molecule is irreversibly split in contrast to $\mathrm{CO}_{2}$ which is released again by respiration processes, we took into account the Gross Primary Productivity (GPP) representing the true $\mathrm{CO}_{2}$ leaf flux the $\mathrm{COS}$ uptake has to be related to. Such a GPP based deposition estimate ranged between $1.4-2.8 \mathrm{Tg} \mathrm{a}^{-1}\left(0.73-1.50 \mathrm{Tg} \mathrm{S} \mathrm{a}^{-1}\right)$. We believe that in order to obtain accurate global COS sink estimates such a GPP-based estimate corrected by the different deposition velocities of $\mathrm{COS}$ and $\mathrm{CO}_{2}$ must be taken into account.
\end{abstract}

\section{Introduction}

Carbonyl sulfide (COS) is a substantial source for stratospheric sulfate aerosol and plays an important role in stratospheric ozone chemistry (Crutzen, 1976; Andreae and Crutzen, 1997). According to Watts (2000) and Kettle et al. (2002) total global sources and sinks are balanced within

Correspondence to: J. Kesselmeier

(jks@mpch-mainz.mpg.de) the uncertainties of the estimates. Deposition to vegetation and soils represents the main sink for this trace gas (Logan et al., 1979; Brown and Bell, 1986; Chin and Davis, 1993, 1995; Geng and Mu, 2004). Soils have been recognized as a global sink for COS only recently and the uncertainty is rather large as parameterization of the uptake has been performed with only one soil type to date (Kesselmeier et al., 1999), which clearly warrants further studies. The role of vegetation as a major global tropospheric sink for COS has been studied for 20 years and is undisputed, but the uncertainty in the quantitative estimates of this sink is still large. Two common methods for the estimate of the global COS sink strength were reported. The estimate by Brown and Bell (1986) is based on the deposition velocity of COS and its atmospheric concentration. Another approach is described by Chin and Davis (1993) who used the correlation between the $\mathrm{COS}$ deposition and the $\mathrm{CO}_{2}$ assimilation, assuming the same deposition velocities for $\mathrm{CO}_{2}$ and COS. Recent estimates refer to this method (Kesselmeier and Merk, 1993; Andreae and Crutzen, 1997; Watts, 2000; Kettle et al., 2002). However, a simple 1:1 relation for the uptake ratio of $\mathrm{COS} / \mathrm{CO}_{2}$ appears insufficient as a preferential uptake of COS on a leaf as well enzymatic basis has been reported (Kesselmeier and Merk, 1993; Protoschill-Krebs et al., 1996). Therefore, we studied the stomatal uptake of COS separately. Moreover we investigated the close correlation between the rate of photosynthesis and the COS uptake for several European tree species and considered the differences in deposition velocities for $\mathrm{CO}_{2}$ and $\mathrm{COS}$. The observed ratios of the deposition velocities were used to improve global estimates of the COS vegetation sink based on Net Primary Production.

(C) 2005 Author(s). This work is licensed under a Creative Commons License. 


\section{Materials and methods}

\subsection{Plant material and growth}

For all experiments young trees (3-4 years old) from German and English tree nurseries were used. Tree species investigated were Holm oak (Quercus ilex L.), European beech (Fagus sylvatica L.), Norwegian spruce (Picea abies) and Scots pine (Pinus sylvestris). The trees were kept in 201 pots with gardener's compost for the years 1997-2000 and fertilized with commercially available fertilizer (Baumfit, SpiessUrania, Germany). For the Mediterranean tree species Quercus ilex sand was mixed with the soil in a 1 to 2 ratio. The trees were grown in a greenhouse at $25^{\circ} \mathrm{C}$ under a $12 / 12 \mathrm{~h}$ light-dark regime with a light intensity of $600 \mu \mathrm{mol} \mathrm{m}^{-2} \mathrm{~s}^{-1}$ of photons (PAR) and a relative humidity of $70 \%$ under 350 ppm $\mathrm{CO}_{2}$.

\subsection{Purification of ambient air}

Compressed air was purified by passing it $\left(61 \mathrm{~min}^{-1}\right)$ through a multistage gas purification system consisting of (1) silica gel (Merck, Germany), (2) molecular sieve (0.5 nm, Merck, Darmstadt), (3) charcoal (Merck,Germany), and soda lime (Merck, Germany), 31 each. $\mathrm{COS}$ and $\mathrm{CO}_{2}$ mixing ratios were adjusted to desired values by mixing the purified compressed air with known gas mixtures produced from a permeation device (Haunold, Germany) with COS permeation tubes (VICI Metronics, Santa Clara, California) and $\mathrm{CO}_{2}$ from a pressurized bottle (Messer-Griesheim, Germany). All flows were regulated by mass flow controllers (MKS, Massachusetts, USA).

\subsection{Enclosure system (cuvettes) and exchange measure-} ments

Gas exchange of enclosed tree branches was investigated using a dynamic (flow-through) Teflon-film-cuvette system consisting of a plant measuring and an empty reference cuvette with all inner surfaces made of Teflon to avoid interference with the investigated trace gases. All experiments were performed in a climate chamber with identical conditions as compared to the growth chamber. Trace gas sampling was accompanied by measurements of ambient $\mathrm{CO}_{2}$, $\mathrm{CO}_{2}$ exchange and transpiration by an infra-red gas analyzer. For details see Kuhn et al. (1999, 2000) and Kuhn and Kesselmeier (2000). Leaf area was determined by copying leaf contours onto paper in order not to destroy the leaves. The area was measured by a calibrated scanner system (ScanJET IICX with DeskSCAN II; both Hewlett-Packard, USA), and SIZE 1.10 (Müller, Germany). The enclosures were constantly flushed with $11 \mathrm{~min}^{-1}$ of purified and conditioned ambient air (see above) which was artificially moistened (r.H. $>70 \%$ ) before entering the cuvettes. COS was quantified in the ppt range by an automated analytical system according to Von Hobe et al. (2000) by consecutive sampling at both cuvettes. The gas exchange rates $(F)$ were calculated from the measured concentration difference $\left(\delta_{c}=c_{\text {sample }}-c_{\text {ref }}\right)$, the chamber flush rate $(Q)$ and the enclosed leaf area $(A)$.

$F=\delta c *(Q / A)$.

Deposition velocities $\left(V_{d}\right)$ related to stomatal conductance were calculated in relation to the ambient air concentration of the reference cuvette $\left(c_{r e f}\right)$.

$V_{d}=F / c_{r e f}$

Accuracy and precision of the analytical system were better than $2 \%$ plus any uncertainties introduced by the cuvette sampling, mainly by the accuracy of mass flow controllers. The stomatal conductance for water vapor was determined according to Pearcy et al. (1989).

\subsection{Induction of stomatal closure}

Stomatal closure was induced by infiltration of abscisic acid (ABA) to an oak branch cut from the tree two days before this application. The ABA treatment was performed by cutting a small branch of Quercus ilex under water (to prevent air from penetrating into the water-conducting elements) and dipping it into a nutrient solution of $1.0 \mathrm{mM} \mathrm{KCl}, 0.1 \mathrm{mM} \mathrm{NaCl}$, $0.1 \mathrm{mM} \mathrm{CaCl}_{2}$. Measurements of $\mathrm{CO}_{2}$ exchange and water vapor transpiration proved the unrestricted viability of this sample branch. ABA was applied by exchanging the nutrient solution against a fresh one containing additional $0.1 \mathrm{mM}$ ABA, which was transported into the leaves by the transpiration stream. For details see Gabriel et al. (1999).

\section{Results}

\subsection{Stomatal uptake}

The automated analytical COS analyzer allowed a dense protocol to follow the exchange behavior with high time resolution. Figure 1 shows the COS uptake by an enclosed branch of Fagus sylvatica (European beech) in relation to assimilation and stomatal conductance over nearly three days of measurements. The COS-uptake closely followed the light/dark cycle. This behavior can be related to the calculated stomatal aperture and consequently directly compared to the exchange of $\mathrm{CO}_{2}$, i.e. net photosynthetic assimilation rate. Low uptake rates were found under dark conditions. As the stomata did not completely close in the dark and a respiration activity was detectable, the low COS exchange may be understood as a physiological consumption at a lower rate. On the other hand we do not exclude fluctuations and scatter caused by the non-simultaneous COS sampling at the sample and reference cuvette due to switching of the automated system from one cuvette to the other. Nevertheless, a clear relation to light and stomatal aperture is obvious, though the enzymatic pathway of COS consumption by carbonic anhydrase itself is generally light independent (Protoschill-Krebs et al., 1996). 


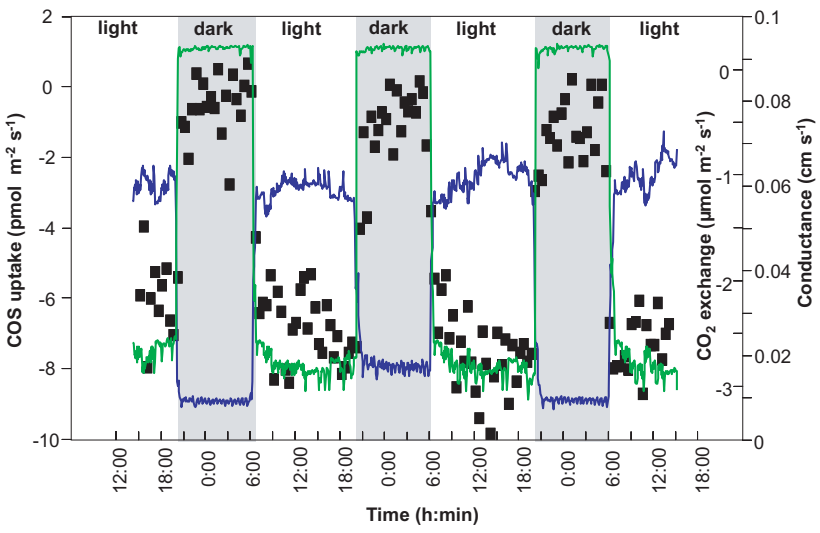

Fig. 1. Exchange (negative=uptake) of carbonyl sulfide (COS, filled squares) in relation to branch (leaf) conductance (blue line) as a measure of stomatal pore width and $\mathrm{CO}_{2}$ exchange (green line) with negative values for uptake (assimilation) and positive values for emission (respiration) for European beech (Fagus sylvatica L.).

The close relation between light and COS uptake in contrast to the light independent consumption by the enzyme carbonic anhydrase supports the assumption of an exclusively stomatal uptake pathway, as light represents a considerable trigger of stomatal movement. The final proof for a stomatal related exchange was demonstrated by the application of abscisic acid (ABA), a plant hormone which causes stomatal closure. Treatment with ABA was performed by cutting a small branch of Quercus ilex and incubating the stem into a vial filled with a buffer solution. Under these conditions, the branch was performing a normal behavior of gas exchange and COS uptake (Fig. 2) as followed for two light/dark episodes. In the course of the third light phase we infiltrated $\mathrm{ABA}$ and observed a fast decline of $\mathrm{CO}_{2}$ exchange down to zero (no respiration measurable) closely accompanied by the decrease of COS uptake (Fig. 2). Stomatal conductance also showed a decrease to night values under the influence of $\mathrm{ABA}$ under light conditions, though with some delay which may be understood as inhomogeneous stomatal apertures or slight water condensation on the cuvette walls interfering with the water vapor measurements. However, the prompt decline of assimilation to a zero-exchange of $\mathrm{CO}_{2}$ under light is a most convincing argument for the strict regulation of this trace gas exchange by stomatal aperture.

\subsection{Deposition velocities of $\mathrm{COS}$ and $\mathrm{CO}_{2}$}

As described above, an exclusive uptake of COS via the stomatal pathway in close relation to the $\mathrm{CO}_{2}$ exchange could be demonstrated. The simultaneous measurements of the $\mathrm{CO}_{2}$-exchange during all enclosure studies has the potential for a better quantification of the COS uptake. We could directly link the uptake rates of $\mathrm{COS}$ and $\mathrm{CO}_{2}$ by comparing the deposition to the leaves after normalization by the am-

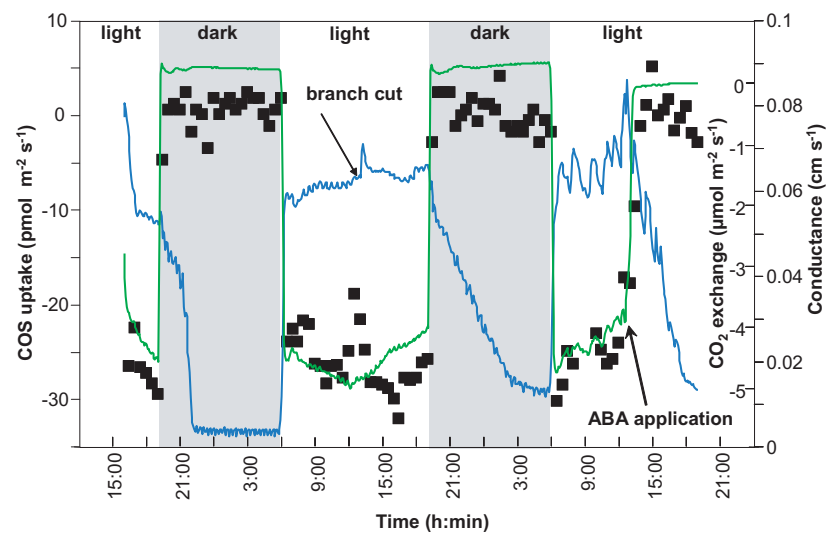

Fig. 2. Exchange (negative=uptake) of carbonyl sulfide (COS, filled squares) in relation to branch conductance (blue line) as a measure of stomatal pore width and $\mathrm{CO}_{2}$ exchange (green line) for Holm oak (Quercus ilex L.) with negative values for uptake (assimilation) and positive values for emission (respiration). Note: Conductance calculated from climate chamber conditions $\left(25^{\circ} \mathrm{C} ; 70 \%\right.$ r.H. $)$.

bient atmospheric concentration of each trace gas, i.e. by comparing deposition velocities $\left(V_{d}\right)$. The obtained COS and $\mathrm{CO}_{2}$ deposition velocities for $F$. sylvatica, $Q$. ilex, $P$. sylvestris and $P$. abies are summarized in Table 1. A clear preference for COS deposition is indicated by the uptake ratios of $V_{d} \mathrm{COS}$ versus $V_{d} \mathrm{CO}_{2}$ and was found for all tree species investigated. The results reflect a significantly pronounced uptake of $\mathrm{COS}$ over $\mathrm{CO}_{2}$ by a factor between 1.4 and 3.4.

In order to widen our basis for further calculations, deposition velocities as reported in or calculated from published data sets were additionally taken into account. In some cases we were able to re-estimate data on the basis of the published figures and tables. For our own data sets published recently, we calculated on the basis of the original data. The results are shown in Table 2. The $V_{d}$-ratios are sensitive to the rate of $\mathrm{CO}_{2}$ uptake taken into account. In case of enclosure measurements we used the net exchange as measured with the enclosed branch or leaf (Net Primary Productivity; $\mathrm{NPP}_{\text {cuvette }}$ ) in order to compare with other published data. However, in case of one data set (spruce forest, Xu et al. 2002) from flux studies above the forest, a correction might be necessary, as this flux value is representing the net exchange as a result of gross photosynthesis minus autotrophic (=NPP) and heterotrophic (soils) respiration. For the enclosure related data we found a range of $V_{d_{\mathrm{COS}}} / V_{d_{\mathrm{CO}_{2}}}$ between 1.3 and 5.5 with the exception of 0.4 for non fertilized pea plants (Kesselmeier and Merk, 1993), 7.0 for young corn plants (Hoffmann, 1993) and 8.7-10.3 for a spruce enclosure study (Huber, 1994). These extraordinary numbers may be subject of further speculation. Within this context, $\mathrm{C}_{4}$ plants need some special discussion. As shown in table 2, Zea mays seems to fit quite well into the 
Table 1. Leaf area based exchange and deposition velocities $\left(V_{d}\right)$ of $\mathrm{COS}$ and $\mathrm{CO}_{2}$ for Fagus sylvatica and Quercus ilex, growing under $350 \mathrm{ppm} \mathrm{CO} 2$ over $2-3$ years. Three tree individuals $\left(T_{1}-T_{3}\right)$ were grown and investigated. COS-exchange data were obtained under an atmospheric COS mixing ratio of 600 ppt. Pinus sylvestris and Picea abies were only measured in one year.

\begin{tabular}{|c|c|c|c|c|c|c|c|c|c|c|c|c|}
\hline Plant Species & & $\begin{array}{l}\text { COS Uptake } \\
\left(\mathrm{pmol} \mathrm{m}^{-2} \mathrm{~s}^{-1}\right)\end{array}$ & $\pm \mathrm{SD}$ & $\begin{array}{l}V_{d} \mathrm{COS} \\
\left(\mathrm{mm} \mathrm{s}^{-1}\right)\end{array}$ & $\pm \mathrm{SD}$ & (n) & $\begin{array}{l}\mathrm{CO}_{2} \text { Uptake } \\
\left(\mu \mathrm{mol} \mathrm{m}^{-2} \min ^{-1}\right)\end{array}$ & $\pm \mathrm{SD}$ & $\begin{array}{l}V_{d} \mathrm{CO}_{2} \\
\left(\mathrm{~mm} \mathrm{~s}^{-1}\right)\end{array}$ & $\pm \mathrm{SD}$ & (n) & $V_{d} \mathrm{COS} / V_{d} \mathrm{CO}_{2}$ \\
\hline F. sylvatica & $T_{1}$ & 13.8 & 4.8 & 0.551 & 0.211 & 19 & 171 & 12 & 0.199 & 0.022 & $>57$ & $2.77(1.54-4.31)$ \\
\hline \multirow[t]{2}{*}{ Summer 1998} & $T_{2}$ & 12.5 & 3.0 & 0.441 & 0.168 & 21 & 193 & 8 & 0.225 & 0.021 & $>51$ & $1.96(1.11-2.99)$ \\
\hline & $T_{3}$ & 12.3 & 4.7 & 0.429 & 0.226 & 36 & 238 & 7 & 0.277 & 0.025 & $>69$ & $1.55(0.67-2.60)$ \\
\hline F. sylvatica & $T_{1}$ & 21.7 & 4.8 & 0.873 & 0.217 & 28 & 317 & 29 & 0.370 & 0.046 & $>84$ & $2.36(1.58-3.36)$ \\
\hline \multirow[t]{2}{*}{ Summer 1999} & $T_{2}$ & 26.1 & 13.7 & 1.105 & 0.486 & 33 & 332 & 27 & 0.387 & 0.046 & $>99$ & $2.86(1.43-4.67)$ \\
\hline & $T_{3}$ & 19.1 & 8.5 & 0.994 & 0.268 & 43 & 354 & 25 & 0.290 & 0.078 & $>129$ & $3.43(1.97-5.95)$ \\
\hline F. sylvatica & $T_{1}$ & 11.3 & 5.1 & 0.460 & 0.221 & 54 & 204 & 6 & 0.238 & 0.022 & $>162$ & $1.93(0.92-3.15)$ \\
\hline \multirow[t]{2}{*}{ Fall 1999} & $T_{2}$ & 11.5 & 6.4 & 0.470 & 0.271 & 71 & 241 & 17 & 0.281 & 0.031 & $>213$ & $1.67(0.64-2.96)$ \\
\hline & $T_{3}$ & 14.1 & 0.5 & 0.575 & 0.094 & 99 & 201 & 5 & 0.234 & 0.021 & $>297$ & $2.46(1.89-3.14)$ \\
\hline Q. ilex & $T_{1}$ & 15.1 & 6.9 & 0.612 & 0.279 & 27 & 283 & 44 & 0.330 & 0.059 & $>81$ & $1.86(0.86-3.29)$ \\
\hline \multirow[t]{2}{*}{ Summer 1998} & $T_{2}$ & 12.9 & 4.9 & 0.542 & 0.210 & 50 & 197 & 14 & 0.229 & 0.026 & $>150$ & $2.37(1.30-3.70)$ \\
\hline & $T_{3}$ & 14.8 & 6.4 & 0.679 & 0.189 & 19 & 180 & 9 & 0.210 & 0.021 & $>57$ & $3.23(2.12-4.59)$ \\
\hline Q. ilex & $T_{1}$ & 16.4 & 4.6 & 0.751 & 0.166 & 33 & 347 & 25 & 0.404 & 0.045 & $>99$ & $1.86(1.30-2.55)$ \\
\hline \multirow[t]{2}{*}{ Summer 1999} & $T_{2}$ & 14.4 & 2.7 & 0.514 & 0.164 & 44 & 308 & 22 & 0.359 & 0.040 & $>152$ & $1.43(0.88-2.13)$ \\
\hline & $T_{3}$ & 15.4 & 3.4 & 0.700 & 0.113 & 29 & 318 & 17 & 0.371 & 0.037 & $>87$ & $1.89(1.44-2.43)$ \\
\hline Q. ilex & $T_{1}$ & 25.8 & 2.1 & 0.673 & 0.372 & 120 & 179 & 16 & 0.208 & 0.026 & $>360$ & $3.24(1.29-5.74)$ \\
\hline \multirow[t]{2}{*}{ Winter 1999/2000 } & $T_{2}$ & 25.1 & 1.5 & 0.575 & 0.263 & 81 & 318 & 17 & 0.371 & 0.037 & $>243$ & $1.55(0.76-2.51)$ \\
\hline & $T_{3}$ & 23.1 & 2.5 & 0.733 & 0.219 & 94 & 289 & 23 & 0.336 & 0.039 & $>282$ & $2.18(1.37-3.21)$ \\
\hline $\begin{array}{l}\text { P. sylvestris } \\
\text { Fall } 2002\end{array}$ & $T_{1}$ & 21.1 & 1.7 & 0.743 & 0.035 & 23 & 298 & 22 & 0.427 & 0.021 & $>69$ & $1.74(1.58-1.92)$ \\
\hline $\begin{array}{l}\text { P. abies } \\
\text { Fall } 2002\end{array}$ & $T_{1}$ & 12.6 & 1.7 & 0.435 & 0.060 & 43 & 275 & 20 & 0.459 & 0.023 & $>129$ & $0.95(0.78-1.14)$ \\
\hline
\end{tabular}

scheme as obtained for the majority of $\mathrm{C}_{3}$ plants. The $V_{d^{-}}$ ratios ranged near to 3 , indicating a similar preference for COS. Very young plants even showed much higher ratios. In contrast, a recent study (Yonemura et al., 2005) reported a $V_{d}$-ratio for Sorghum, another $\mathrm{C}_{4}$ grass, ranging around one, thus exhibiting no preferred uptake of COS. The authors related this behaviour to be caused by low carbonic anhydrase content which could not be balanced by the activity of the enzymes Phosphoenolpyruvate-Carboxylase (PEP-Co) and Ribulose-1,5-Bisphosphate-Carboxylase (Rubisco), both also principally capable to consume COS (Protoschill-Krebs and Kesselmeier 1992). Further studies on the enzymatic regulation of COS-uptake are crucially needed, especially for $\mathrm{C}_{4}$ plants.

\subsection{Corrected estimate of a global sink strength for COS}

The data presented above on the uptake of COS normalized to the net assimilation or gross assimilation, respectively, allows a new global sink strength to be estimated for the vegetation (Table 3). Our calculations were based on deposition velocity $\left(V_{d}\right)$ ratios of $\operatorname{COS}$ versus $\mathrm{CO}_{2}$ fluxes according to Eq. (1).

$J_{\mathrm{COS}}=J_{\mathrm{CO}_{2}} \times[\mathrm{COS}] /\left[\mathrm{CO}_{2}\right] \times V_{d_{\mathrm{COS}}} / V_{d_{\mathrm{CO}_{2}}}$

with

$J_{\mathrm{COS}} \quad$ global COS uptake $\left(\mathrm{mol} \mathrm{m} \mathrm{m}^{-2} \mathrm{~s}^{-1}\right)$

$J_{\mathrm{CO}_{2}} \quad$ global $\mathrm{CO}_{2}$ uptake $\left(\mathrm{mol} \mathrm{m}^{-2} \mathrm{~s}^{-1}\right)$
[COS] atmospheric COS mixing ratio $\left(\mathrm{mol} \mathrm{m}^{-3}\right)$

$\left[\mathrm{CO}_{2}\right]$ atmospheric $\mathrm{CO}_{2}$ mixing ratio $\left(\mathrm{mol} \mathrm{m}^{-3}\right)$

$V_{d_{\mathrm{COS}}} \quad$ COS deposition velocity $\left(\mathrm{m} \mathrm{s}^{-1}\right)$

$V_{d_{\mathrm{CO}_{2}}} \quad \mathrm{CO}_{2}$ deposition velocity $\left(\mathrm{m} \mathrm{s}^{-1}\right)$.

For global $\mathrm{CO}_{2}$ fluxes we considered net primary productivity (NPP). NPP dry matter data according to Whittaker and Likens (1975) and Lieth (1975) were recalculated to NPP carbon according to Larcher (1994). Based on our observations of different deposition velocities we assigned ecotype related $V_{d}$-ratios and recalculated the COS sinks accordingly. For each ecotype we tried to take into account the exchange behavior of typical plant species. Based on our compilation in Table 2 we were able to assign a $V_{d}$-ratio for each ecotype except for "Extreme desert" and "Swamp and marsh". Instead a best guess was used. The results show that tropical and boreal forests, as well as savannas, are of highest significance for a global estimate of the vegetation sink strength. A ranking of ecotype-significance for the global budget shows that tropical rainforest contributes most, followed by tropical seasonal forest, savannah, boreal forest, cultivated land, temperate deciduous and evergreen forest, to an overall NPP based total COS sink strength of $0.69-1.4 \mathrm{Tg} \mathrm{a}^{-1}$.

\section{Discussion}

The exchange of COS between the atmosphere and higher plants, algae, lichens, as well as soil has been reported to 
Table 2. Carbonyl sulfide (COS) deposition velocities $\left(V_{d}\right)$ and normalized net uptake as expressed in the $V_{d}-$ ratio of $\mathrm{COS}_{\text {and }} \mathrm{CO}_{2}$. Data as obtained in the course of this study by measurements and recalculations from published data compared to available literature values of measurements in the field, and laboratory (lab.) mainly with enclosures (encl.) or by relaxed eddy accumulation (REA) measurements.

\begin{tabular}{|c|c|c|c|c|c|}
\hline Plant species & $\begin{array}{l}\text { COS } \\
\text { deposition } \\
\text { velocity }\end{array}$ & $\begin{array}{l}\text { Normalized } \\
\text { relation } \\
\text { COS } / \mathrm{CO}_{2} \\
\text { net uptake } \\
\left(V_{d \mathrm{COS}} / V_{d \mathrm{CO}_{2}}\right)\end{array}$ & $\begin{array}{l}\text { Atmospheric } \\
\text { concentration }\end{array}$ & Remarks & Reference \\
\hline & $\left(\mathrm{mm} \mathrm{s}^{-1}\right)$ & & (ppt) & & \\
\hline CROPS & & & & & \\
\hline Allium cepa & $0.29-0.35$ & & 4000 & Lab., light, encl. & 1 \\
\hline Brassica campestris ssp. & $0.47-0.56$ & & 4000 & Lab., light, encl. & 1 \\
\hline Brassica napus & 1.24 & 1.25 & $50-300$ & Lab., light, encl. & 7 \\
\hline Brassica oleracea ssp. & $0.46-0.52$ & & 4000 & Lab., light, encl. & 1 \\
\hline Glycine $\max$ & 3.1 & & 2000 & Lab., light, encl. & 2 \\
\hline Glycine $\max$ & 0.71 & & 500 & Lab., light, encl. & 3 \\
\hline Lactuca sativa & $0.25-0.35$ & & 4000 & Lab., light, encl. & 1 \\
\hline Lolium perenne & 0.78 & & 4000 & Lab., light, encl. & 1 \\
\hline Lycopersicon esculentum & 0.4 & & 2000 & Lab., light, encl. & 2 \\
\hline Medicago sativa & 1.6 & & 500 & Lab., light, encl. & 3 \\
\hline Phaseolus vulgaris & 1.4 & & 2000 & Lab., light, encl. & 2 \\
\hline Pisum sativum. non fert. & 0.2 & 0.4 & $300-900$ & Lab., light, encl. & 7 \\
\hline Pisum sativum. fert. & 1.1 & 3.8 & $300-900$ & Lab., light, encl. & 7 \\
\hline Pisum sativum. fert. & $1.03^{\&}$ & $3.1^{\&}$ & 820 & Lab., light, encl & 8 \\
\hline Raphanus sativus & 0.57 & & 4000 & Lab., light, encl. & 1 \\
\hline Spinacia oleracea & 0.4 & & 4000 & Lab., light, encl. & 1 \\
\hline Triticum aestivum & 1.54 & & 500 & Lab., light, encl. & 3 \\
\hline Triticum aestivum $(10 \mathrm{~d})$ & $1.08^{\&}$ & $3.2^{\&}$ & 360 & Lab., light, encl & 8 \\
\hline Zea mays & 1.14 & & 500 & Lab., light, encl. & 3 \\
\hline Zea mays & 0.69 & 2.85 & $100-900$ & Lab., light, encl. & 7 \\
\hline Zea mays (9-12 d) & $2.36^{\&}$ & $7.0^{\&}$ & 740 & Lab., light, encl. & 8 \\
\hline $\begin{array}{l}\text { Grass, not specified } \\
\text { TREES }\end{array}$ & $0.11-2.02$ & & $400-1500$ & Field, light \& dark, encl. & 10 \\
\hline Fagus sylvatica & $0.66 \pm 0.26$ & $2.33 \pm 0.62$ & 600 & Lab., light, encl. & This work \\
\hline Picea abies & $0.4-1.8$ & $<7 \S$ & atmospheric & Field, light, REA & 4 \\
\hline Picea abies & $0.26(0.5 \max )$ & $8.7-10.3^{\&}$ & $300-650$ & Field, light, encl. & 6 \\
\hline Picea abies & $0.46 \pm 0.023$ & 0.95 & 700 & Lab., light, encl. & This work \\
\hline Pinus sylvestris & $0.43 \pm 0.021$ & 1.74 & 700 & Lab., light, encl. & This work \\
\hline Porterandia cladantha & $0.23(\max )$ & $2.37^{\S \S}$ & $400-600$ & Field, light, encl. & 9 \\
\hline Quercus agrifolia & $0.44^{\S}$ & $1.8^{\S}$ & $300-500$ & Field, light, encl. & 5 \\
\hline Quercus ilex & $0.64 \pm 0.09$ & $2.18 \pm 0.66$ & 600 & Lab., light, encl. & This work \\
\hline Sacoglottis gabonensis & $0.04^{\S \S}$ & $1.74^{\S \S}$ & $400-600$ & Field, light, encl. & 9 \\
\hline Sacoglottis gabonensis & $0.09^{\S \S}$ & $5.49^{\S \S}$ & $400-600$ & Field, light, encl. & 9 \\
\hline
\end{tabular}

Note: No correction was applied to take into account the decrease of the measured net $\mathrm{CO}_{2}$ exchange by respiration (Net uptake). Hence, considering a gross photosynthetic uptake by increasing the $\mathrm{CO}_{2}$ uptake can lead to significantly reduced values for the normalized $\mathrm{COS} / \mathrm{CO}_{2}-$ uptake in case of data obtained by flux studies above the forest with the influence of stem and soil respiration.

$\S$ recalculated based on published fluxes and atmospheric mixing ratios of $500 \mathrm{ppt}$ for COS and $350 \mathrm{ppm}$ for $\mathrm{CO}_{2}$.

$\S \S$ recalculated considering maximal $\mathrm{V}_{d}$ - values only.

$\&$ calculated on actual data as given in the paper.

Literature cited: ${ }^{1}$ Kluczewski et al. (1985); ${ }^{2}$ Taylor et al. (1983); ${ }^{3}$ Goldan et al. (1988); ${ }^{4}$ Xu et al. (2002); ${ }^{5}$ Kuhn et al. (1999); ${ }^{6}$ Huber (1994); ${ }^{7}$ Kesselmeier and Merk (1993); ${ }^{8}$ Hofmann (1993); ${ }^{9}$ Kesselmeier et al. (1993); ${ }^{10}$ Geng and Mu (2004).

be governed by the actual ambient concentrations and to exhibit a compensation point, i.e. describing the atmospheric concentration where uptake and emission are balanced and the net exchange is zero (Goldan et al., 1988; Kesselmeier and Merk, 1993; Conrad, 1994; Blezinger et al., 2000; Kesselmeier et al., 1999; Kuhn et al., 1999; Conrad and Meuser, 2000; Kuhn and Kesselmeier, 2000, Geng and Mu, 2004). However, in case of vegetation all reported com- 
Table 3. Estimate of global sink strength for carbonyl sulfide (COS) based on deposition velocity $\left(\mathrm{V}_{d}\right)$ ratios of $\mathrm{COS}_{\text {versus }} \mathrm{CO}_{2}$ of typical plant species and net primary productivity (NPP). NPP dry matter data according to Whittaker and Likens (1975) and Lieth (1975) recalculated to NPP carbon according to Larcher (1994).

\begin{tabular}{|c|c|c|c|c|c|c|c|c|}
\hline Ecosystem type & $\begin{array}{l}\text { Area } \\
\left(10^{6} \mathrm{~km}^{2}\right)\end{array}$ & $\begin{array}{l}\text { NPP } \\
\text { dry matter } \\
\left(\mathrm{g} \mathrm{m}^{-2} \mathrm{a}^{-1}\right)\end{array}$ & $\begin{array}{l}\text { NPP } \\
\text { dry matter } \\
\left(10^{9} \mathrm{t} \mathrm{a}^{-1}\right) \\
\end{array}$ & $\begin{array}{l}\text { NPP } \\
\text { C } \\
\left(10^{15} \mathrm{~g} \mathrm{a}^{-1}\right)\end{array}$ & $\begin{array}{l}\text { NPP } \\
\mathrm{CO}_{2} \\
\left(10^{15} \mathrm{~g} / \mathrm{a}\right)\end{array}$ & $\begin{array}{l}V_{d} \text { ratios } \\
\mathrm{COS} / \mathrm{CO}_{2} \\
\min -\max \end{array}$ & $\begin{array}{l}F_{\mathrm{COS}} \\
\mathrm{Tg} / \mathrm{a} \\
\min -\max \end{array}$ & $\begin{array}{l}\text { Plant species related } \\
V_{d} \text { assigned } \\
\text { (see Table } 2)\end{array}$ \\
\hline Tropical rain forest & 17 & 2200 & 37.40 & 16.46 & 60.34 & $1.7-3.6$ & $0.246-0.508$ & $\begin{array}{l}\text { S. gabonensis. } \\
\text { P. cladantha }\end{array}$ \\
\hline Tropical seasonal forest & 7.5 & 1600 & 12.00 & 5.28 & 19.36 & $1.7-3.6$ & $0.079-0.163$ & $\begin{array}{l}\text { S. gabonensis. } \\
\text { P. cladantha }\end{array}$ \\
\hline Temperate evergreen forest & 5 & 1300 & 6.50 & 2.86 & 10.49 & $1.5-2.9$ & $0.037-0.071$ & Q. ilex, Q. agrifolia \\
\hline Temperate deciduous forest & 7 & 1200 & 8.40 & 3.70 & 13.55 & $1.7-3.0$ & $0.054-0.095$ & F. sylvatica \\
\hline Boreal forest & 12 & 800 & 9.60 & 4.22 & 15.49 & $1-1.7$ & $0.036-0.063$ & P. abies, $P$. sylvestris \\
\hline Woodland and scrubland & 8.5 & 700 & 5.95 & 2.62 & 9.60 & $1.5-2.9$ & $0.034-0.065$ & $Q$. ilex, $Q$. agrifolia \\
\hline Savannah & 15 & 900 & 13.50 & 5.94 & 21.78 & $1.5-2.9$ & $0.076-0.148$ & Q. ilex, Q. agrifolia \\
\hline Temperate grassland & 9 & 600 & 5.40 & 2.38 & 8.71 & $2.0-3.0$ & $0.041-0.061$ & Z. mays, T. aestivum \\
\hline Tundra and alpine & 8 & 140 & 1.12 & 0.49 & 1.81 & $2.0-3.0$ & $0.008-0.013$ & best guess \\
\hline Desert and semi desert scrub & 18 & 90 & 1.62 & 0.71 & 2.61 & $1.5-2.9$ & $0.009-0.018$ & $Q$. ilex, $Q$. agrifolia \\
\hline Extreme desert. rock. sand. ice & 24 & 3 & 0.07 & 0.03 & 0.12 & $1.0-3.0$ & $0.000-0.001$ & best guess \\
\hline Cultivated land & 14 & 650 & 9.10 & 4.00 & 14.68 & $1.3-3.8$ & $0.043-0.130$ & $\begin{array}{l}\text { Z. mays, T. aestivum, } \\
\text { B. Napus, P. sativum }\end{array}$ \\
\hline \multirow[t]{2}{*}{ Swamp and marsh } & 2 & 3000 & 6.00 & 2.64 & 9.68 & $1.0-3.0$ & $0.023-0.068$ & best guess \\
\hline & & & & & & TOTAL & $0.686-1.404$ & \\
\hline
\end{tabular}

Table 4. Estimates of the global COS sink strength for terrestrial vegetation.

\begin{tabular}{lll}
\hline $\mathrm{Tg} \mathrm{a}^{-1}$ & Source & Parameters considered \\
\hline $2-5$ & Brown and Bell (1986) & $V_{d}, \mathrm{LAI}$, Area, COS atmospheric conc. \\
5.6 & Servant (1989) & $V_{d}, \mathrm{LAI}$, Area, COS atmospheric conc. \\
$0.2-0.6$ & Goldan et al. (1988) & $R_{\mathrm{COS}}=R_{\mathrm{CO}_{2}}$, atmospheric conc., $\mathrm{CO}_{2}$ uptake \\
$0.93 \pm 0.07$ & Kesselmeier and Merk (1993) & $V_{d} \mathrm{COS}=V_{d} \mathrm{CO}_{2}$, atmospheric ratios, $\mathrm{CO}_{2}$ uptake \\
$0.16-0.91$ & Chin and Davis (1993) & $V_{d} \mathrm{COS}=V_{d} \mathrm{CO}_{2}$, atmospheric ratios, $\mathrm{CO}_{2}$ uptake \\
0.32 & Kjellstrøm (1998) & $V_{d} \mathrm{COS}=V_{d} \mathrm{CO}_{2}$, atmospheric ratios, $\mathrm{CO}_{2}$ uptake \\
$0.56 \pm 0.1$ & Watts (2000) & $V_{d} \mathrm{COS}=V_{d} \mathrm{CO}_{2}$, atmospheric ratios, $\mathrm{CO}_{2}$ uptake \\
$0.21-0.27$ & Kettle et al. (2002) & Surface flux model, $V_{d} \mathrm{COS}=V_{d} \mathrm{CO}_{2}$, atmospheric ratios, $\mathrm{CO}_{2}$ uptake \\
$2.3 \pm 0.5$ & Xu et al. (2002) & $\mathrm{Uptake} \mathrm{ratio} \mathrm{COS} / \mathrm{CO}_{2}, \mathrm{CO}{ }_{2}$ uptake \\
$1.37-2.81$ & This work & $V_{d} \mathrm{COS}>V_{d} \mathrm{CO}_{2}$, atmospheric ratios, $\mathrm{CO}_{2}$ uptake \\
\hline
\end{tabular}

pensation points are much lower than the observed ambient concentration ranges. Furthermore, within our reported experiments we never observed any COS emission, even under COS-free air. Moreover, by incorporating the deposition velocities of $\mathrm{COS}$ and $\mathrm{CO}_{2}$ instead of their uptake ratios we already considered the linear relationship between the exchange of a trace gas and its atmospheric concentration. Thus, we assume that neither a compensation point nor the relationship between uptake and atmospheric concentration will interfere with our interpretations and estimates.

The close relation of COS uptake to photosynthesis and the clear consumption pathway via stomatal uptake allowed a recalculation of the COS uptake by terrestrial vegetation. We regard this $V_{d}$-ratio-corrected estimate of the COS sink strength to be necessary when estimating a COS sink strength from NPP and regard earlier estimates not taking such a correction into account as to be too low. Furthermore, we have to consider that COS is taken up and consumed without be- ing released by the vegetation. COS is irreversibly lost within the biochemical consumption. A production pathway is not known to our knowledge. In contrast, $\mathrm{CO}_{2}$ is clearly produced by respiration processes and its release leads to a carbon loss. Hence, all data on net carbon uptake or net primary production do not consider the gross uptake rates of $\mathrm{CO}_{2}$, which represent the real basis for the uptake relationship between $\mathrm{COS}$ and $\mathrm{CO}_{2}$. As we used the net primary productivity (NPP) data from Whittaker and Likens (1975) for global ecotype depending estimations, the loss by heterotrophic respiration had to be taken into account in order to relate the uptake of COS to the real uptake of $\mathrm{CO}_{2}$. This NPP value represents only around $50 \%$ of the total gross $\mathrm{CO}_{2}$ uptake by vegetation. A $50 \%$ loss by autotrophic respiration, i.e. respiration by the photoautotrophic biological organism itself, has been subtracted from the Gross Primary Productivity (GPP). In contrast, the data resulting from the enclosure measurements represent a net exchange based on the gross 
uptake of $\mathrm{CO}_{2}$ minus the respiration of the leaves and some branches only. We regarded the respiration in the light to be lower than the dark respiration as it may be inhibited in the light (see Shapiro et al., 2004 and literature cited therein). Therefore, we assumed the contribution of the branch respiration to the overall net exchange data to be small as compared to the overall respiration of a whole tree with stem and roots. Hence, in a first attempt we doubled the number for the COS sink in order to relate to the real gross $\mathrm{CO}_{2}$ flux which was the basis for the NPP calculated by Whittaker and Likens (1975). This correction leads to an estimate of a COS sink strength between $1.4-2.8 \mathrm{Tg} \mathrm{a}^{-1}$, equivalent to $0.73-1.5 \mathrm{Tg} \mathrm{a}^{-1}$ on a sulfur basis.

Table 4 gives an overview, comparing the different estimates as reported within the last years. Different procedures have been used based on several parameters such as atmospheric COS concentration, deposition velocity, leaf and ground area as well as the relation of COS deposition to the uptake of $\mathrm{CO}_{2}$. The highest estimates between 2 and $5.6 \mathrm{Tg} \mathrm{a}^{-1}$ were calculated not taking into account the close relation to $\mathrm{CO}_{2}$ assimilation, thus excluding any diurnal and seasonal effect. Much lower values, between 0.2 and $1.0 \mathrm{Tg} \mathrm{a}^{-1}$, supported by a modeling study with similar low estimates (Kettle et al., 2002), were obtained by relating the deposition of $\mathrm{COS}$ to the $\mathrm{CO}_{2}$ assimilation data bases. The latter group, however, did not take into account the preferred uptake and enzymatic consumption of COS as related to the $\mathrm{CO}_{2}$ assimilation. In contrast, the results of Xu et al. (2002), based on flux measurements over a coniferous forest, fit well into such an estimation by taking into account a preferential uptake ratio of $\mathrm{COS} / \mathrm{CO}_{2}$. Including such a preference by correction with the deposition velocity ratios, the new data presented here show that this new procedure results in a significant increase of the COS sink strength calculation again, as productivity, seasonality as well as the preferred uptake is taken into account.

Nevertheless, uncertainties remain large and depend on a still limited data set. A systematic error may be caused by the calculation procedure of the deposition velocity. According to Winner and Greitner (1989), the actual relevant atmospheric conditions for the incubated samples are represented by the concentrations inside the branch cuvette. We agree with the aforementioned authors. However, plotting exchange data against the atmospheric concentrations inside the branch cuvette lead to an increased scatter of the linearization. Therefore, we decided to take the concentrations inside the reference cuvette into account. Hence, as the branch cuvette air exhibited 20-40\% lower COS values due to the consumption by the leaves, our actual result may underestimate $V_{d}$ for COS. Therefore, the final number of the global uptake might also be underestimated by roughly 20 $40 \%$. Influences of climatic factors are minimized as long as the available NPP data are accurate. Closely relating the COS consumption to the NPP means to transfer automatically all environmental parameters affecting $\mathrm{CO}_{2}$ exchange to the COS uptake. Based on a set of enclosure studies we report the net uptake of $\mathrm{CO}_{2}$ in relation to the net uptake of COS. However, in contrast to the net exchange of $\mathrm{CO}_{2}$, which is based on assimilation and respiration, the COS uptake seems to be irreversible under normal atmospheric concentrations. Hence, in case of $\mathrm{CO}_{2}$ we have to add estimates of night- and daytime respiration rates in order to obtain the real Gross Primary Productivity (GPP) which can be regarded as the best basis for any $\mathrm{CO}_{2}$ related estimation of the COS sink strength, as it includes all environmental parameters best. To achieve this goal we need exchange studies covering longer episodes and day/night studies in order to estimate autotrophic respiration for enclosure studies and autotrophic plus heterotrophic respiration for flux studies. Furthermore, we need a better experimental data set especially for tropical and boreal forest trees, as both ecotypes may represent a dominant contribution to the global terrestrial sink strength for COS.

\section{Conclusions}

Taking into account the deposition velocities for the uptake of $\mathrm{COS}$ in relation to $\mathrm{CO}_{2}$ leads to a significant increase of the COS sink strength estimate for terrestrial vegetation in the range of $1.4-2.8 \mathrm{Tg} \mathrm{a}^{-1}$. As the calculation depends on GPP estimates it includes all environmental and seasonal effects. Such an estimate suggests that the vegetation sink strength may have been underestimated in earlier COS budget calculations. This result questions the balance of known sinks and sources. We need to investigate again well known COS sources in order to check their validity. It is beyond our capabilities to state errors, but we seem to have substantial gaps in our knowledge of the COS production and consumption. Undescribed sources may be detected by careful measurements. Within this context the recent report by $\mathrm{Mu}$ et al. (2004) for example about abiotic COS production within rain water is of high interest.

Acknowledgements. We acknowledge the financial support of L. Sandoval-Soto by DAAD as well as the fundamental support by the Max Planck Society in the course of the PhD-studies of L.S.-S. We thank the Zentrum für Umweltforschung (University Mainz) for additional financial support. The authors thank J. Williams for his help with the manuscript.

Edited by: F. X. Meixner

\section{References}

Andreae, M. O. and Crutzen, P. J.: Atmospheric aerosols - Biogeochemical sources and role in atmospheric chemistry, Science, 276, 1052-1058, 1997.

Blezinger S., Wilhelm C., and Kesselmeier, J.: Enzymatic consumption of carbonyl sulfide (COS) by marine algae, Biogeochem., 48, 2, 185-197, 2000. 
Brown, K. A. and Bell, J. N. B.: Vegetation - the missing sink in the global cycle of carbonyl sulfide (COS), Atmos. Env. , 20, 537-540, 1986.

Chin, M. and Davis, D. D.: Global sources and sinks of OCS and $\mathrm{CS}_{2}$ and their distribution, Global Biogeochem. Cycles, 7, 321337, 1993.

Chin, M. and Davis, D. D.: A reanalysis of carbonyl sulfide as a source of stratospheric background sulfur aerosol, J. Geophys. Res., 100, 8993-9005, 1995.

Conrad, R.: Compensation concentration as a critical variable for regulating the flux of trace gases between soil and atmosphere, Biogeochem., 27, 155-170, 1994.

Conrad, R. and Meuser, K.: Soils contain more than one activity consuming carbonyl sulfide, Atmos. Env., 34, 3635-3639, 2000.

Crutzen, P. J.: The possible importance of CSO for the sulfate layer of the stratosphere, Geophys. Res. Lett., 3, 73-76, 1976.

Gabriel, R., Schäfer, L. Gerlach, C., Rausch, T., and Kesselmeier, J.: Factors controlling the emissions of volatile organic acids from leaves of Quercus ilex L. (Holm oak), Atmos. Environment, 33, 1347-1355, 1999.

Geng, C. and Mu, Y.: Carbonyl sulfide and dimethyl sulfide exchange between lawn and the atmosphere, J. Geophys. Res., 109, D12302, doi:10.1029/2003JD004492, 2004

Goldan, P. D., Fall, R., Kuster, W. C., and Fehsenfeld, F. C.: Uptake of COS by growing vegetation - a major tropospheric sink, J. Geophys. Res.-Atmos., 93, D11, 14 186-14 192, 1988.

Hoffmann, U.: Der Austausch von reduzierten SchwefelVerbindungen zwischen Vegetation und Atmosphäre: Interpretation von Versuchen im Freiland in Verbindung mit mechanistischen Experimenten im Labor, Dissertation, Fachbereich Biologie, Universität Mainz, 1993.

Huber, B.: Austausch flüchtiger Schwefelverbindungen in landund forstwirschaftlichen Ökosystemen, Dissertation Techn. Univ. München, 1993. Schriftenreihe des Fraunhofer-Instituts für Atmosphärische Umweltforschung, Bd. 26, Wissenschaftsverlag Dr. W. Maraun, Frankfurt/M, ISBN 3-927548-65-0, 1994.

Kesselmeier, J. and Merk, L.: Exchange of carbonyl sulfide (COS) between agricultural plants and the atmosphere: Studies on the deposition of COS to peas, corn and rapeseed, Biogeochem., 23, 47-59, 1993.

Kesselmeier, J., Meixner, F. X., Hofmann, U., Ajavon, A., Leimbach, St., and Andreae, M. O.: Reduced sulfur compound exchange between the atmosphere and tropical tree species in southern Cameroon, Biogeochem., 23, 23-45, 1993.

Kesselmeier, J., Teusch, N., and Kuhn, U.: Controlling variables for the uptake of atmospheric carbonyl sulfide (COS) by soil, J. Geophys. Res.-Atmos., 104, D9, 11 577-11 584, 1999.

Kettle, A. J., Kuhn, U., von Hobe, M., Kesselmeier, J., and Andreae, M. O.: The Global Budget of Atmospheric Carbonyl Sulfide: Temporal and Spatial Modulation of the Dominant Sources and Sinks, J. Geophys. Res., 107, D22, 4658, 2002, doi:10.1029/2002JD002187.

Kluczewski, S. M., Brown, K. A., and Bell, J. N. B.: Deposition of S-35-Carbonyl Sulfide to vegetable crops, Radiation Protection Dosimetry, 11, 3, 173-177, 1985.

Kuhn, U., Wolf, A., Ammann, C., Meixner, F. X., Andreae, M. O., and Kesselmeier, J.: Carbonyl sulfide exchange on an ecosystem scale: Soil represents a dominant sink for atmospheric COS, Atmos. Environm., 33, 995-1008, 1999.
Kuhn, U., Gries, C., Nash III, T. H., and Kesselmeier, J.: Field measurements on the exchange of carbonyl sulfide between lichens and the atmosphere, Atmos. Environ., 34, 28, 4867-4878, 2000.

Kuhn, U. and Kesselmeier, J.: Environmental parameters controlling the uptake of carbonyl sulfide by lichens, J. Geophys. Res., 105, 22, 26783-26 792, 2000.

Larcher, W.: Ökophysiologie der Pflanzen, 5. Auflage, Eugen U1mer Verlag, Stuttgart, 129, 1994.

Lieth, H.: Modeling the primary productivity of the world, in: Primary productivity of the biosphere, edited by: Lieth, H. and Whittaker, R. H., Springer Verlag, Berlin, 237-283, 1975.

Logan, J. A., McElroy, M. B., Wofsy, S. C., and Prather, M. J.: Oxidation of $\mathrm{CS}_{2}$ and COS: Sources for atmospheric $\mathrm{SO}_{2}$, Nature, 281, 185-188, 1979.

Mu, Y., Gen, C., Wang, M., Wu, H., Zhang, X., and Jiang, G.: Photochemical production of carbonyl sulfide in precipitation, J Geophys. Res., 109, D13301, doi: 10.1029/2003JD004206, 2004.

Pearcy, R. W., Schulze, E. D., and Zimmermann, R.: Measurement of transpiration and leaf conductance, in: Plant Physiological Ecology, Chapman and Hall, New York, 141-142, 1989.

Protoschill-Krebs G and Kesselmeier J.: Enzymatic pathways for the consumption of carbonyl sulphide (COS) by higher plants. Botanica Acta 105, 206-212, 1992.

Protoschill-Krebs, G., Wilhelm, C., and Kesselmeier, J.: Consumption of carbonyl sulfide by carbonic anhydrase (CA) isolated from Pisum sativum, Atmos. Environm., 30, 3151-3156, 1996.

Servant, J.: Les sources et les puits d'oxysulfure de carbone (COS) a l'echelle mondiale, Atmos. Res., 23, 105-116, 1989.

Shapiro, J.B., Griffin, K.L., Lewis, J.D., and Tissue, D.T.: Response of Xanthium strumarium leaf respiration in the light to elevated $\mathrm{CO}_{2}$ concentration, nitrogen availability and temperature, New Phytologist, 162, 377-286, 2004.

Taylor, G. E., McLaughlin S. B., Shriner D. S., and Selvidge W. J.: The flux of sulfur containing gases to vegetation, Atmos. Environm., 17, 789-796, 1983.

Von Hobe, M., Kenntner, T., Helleis, F. H., Sandoval-Soto, L., and Andreae, M. O.: Cryogenic Trapping of Carbonyl Sulfide without Using Expendable Cryogens, Analytical Chemistry, doi10.1021/ac00058fCCC, 2000.

Watts, S. F.: The mass budgets of carbonyl sulfide, dimethyl sulfide, carbon disulfide and hydrogen sulfide, Atmos. Environm., 34, 761-779, 2000.

Winner, W. E. and Greitner, C. S.: Field methods used for air pollution research with plants, in: Plant physiological ecology, edited by: Pearcy, R. W., Ehlinger, J., Mooney, H. A., and Rundel, P. W., Chapman \& Hall, London, 400-425, 1989.

Whittaker, R. H. and Likens, G. E.: The biosphere and man, in: The Primary Productivity of the Biosphere, edited by: Lieth, $\mathrm{H}$. and Whittaker, R. H., Springer Verlag, New York, 305-328, 1975.

$\mathrm{Xu}, \mathrm{X}$., Bingemer, H. G., and Schmid, U.: The flux of carbonyl sulfide and carbon disulfide between the atmosphere and a spruce forest, Atmos. Chem. Phys., 2, 171-181, 2002, SRef-ID: 1680-7324/acp/2002-2-171.

Yonemura, S., Sandoval-Soto, L., Kesselmeier, J., Kuhn, U., Von Hobe, M., Yakir, D., and Kawashima, S.: Uptake of carbonyl sulfide (COS) and emission of dimethyl sulfide (DMS) by plants, Phyton, in press, 2005. 